\title{
Modification of Snakes and Ladder Games as Psychosection Learning Media in Retarded Children
}

\author{
Saskia Putri Rahayu' ${ }^{1}$, Eddy Marheni², Eko Purnomo ${ }^{3}$ \\ ${ }^{1}$ Universitas Negeri Padang, Padang, Indonesia (saskiafajar1998@gmail.com) \\ ${ }^{2}$ Universitas Negeri Padang, Padang, Indonesia (eddymarheni@ fik.unp.ac.id) \\ ${ }^{3}$ Universitas Negeri Padang, Padang, Indonesia (ekopurnomo@ fik.unp.ac.id)
}

\begin{abstract}
The research aims to form the mentality of retardation children. The hope is that through the modification of the game snake ladders, children will gain knowledge of sex, so that the risk of sexual violence and deviant behavior decreases. This study uses a qualitative approach with descriptive methods. This study used 5 informants, with research subjects of 18 mentally disabled students with 10 girls and 8 men. This research was conducted on 2 August - 29 September 2018 at Padang Perwari School, West Sumatra. The results show the lack of sex learning that teachers give to children, so that children usually do deviant behavior in public. Through the medium of this game, children come to understand the boundaries between men hang out with women and can keep themselves when there are foreigners who want to hold and abusing it. Looks very enthusiastic about the pictures in each game box.
\end{abstract}

Keywords: Retarded, Sex Education, Learning Media

\section{INTRODUCTION}

The desire of every human being to live a perfect life must always be expected by everyone. But life always goes hand in hand with each other's partners. When There is High then there is short, there is great there is a small, normal and abnormal child and so on. Abnormal children or with special needs are one example of everything in the world there is always a partner or comparison. The term special needs explicitly addressed to children who are considered to have abnormalities or deviations from the average normal children generally, in terms of physical, mental and social behavior characteristics (Efendi,2006).

Some experts also refer to children with special needs are those who have intellectual and developmental disabilities, physical disabilities, sensory disabilities (senses), behavioral obstacles or problems, learning difficulties, and intelligent and special talents (Blackhurst, A. E., \&Berdine, W. H., 1981:7-8). Children with special needs are also divided into several types according to social characteristics, mental disorders and physical abnormalities. One of the children with a mental disorder is a mentally retarded child. Children with intellectual 
disabilities are children who actually experience barriers to the function of intellectual intelligence and behavioral adaptation that occur during their development and also cause difficulties in academic, communication and social tasks, and therefore require special education services (Wahyu. Y. 2016). Children who have needs in mental aspects include children who have more mental abilities (super normal) who are known as gifted children or superior children and who have very low (abnormal) mental abilities known as mentally retarded (Abdullah Nandiyah, 2013). Retardation is the origin of the word tuna which means 'loss' while retarded means 'mind' and other words of mental retardation are other words of mental retardation which means mental retardation, and mental retardation also has the following terms:

a. feeble minded

b. mentally retarded

c. stupid or stupid (idiot)

d. mental disability

e. subnormal mentality, etc.

Sexual violence happens to many children with special needs are more severe mental retardation in children. Because mentally disabled teenagers are also called children who are weak in terms of thinking and not knowing sexuality, therefore do not know puberty which is usually disturbing. Based on data from the Central Statistics Agency in 2017, the number of children with special needs in Indonesia reaches 1.6 million children. Based on a survey from Indonesia PT Surveyor (persero), the highest population of people with disabilities is in West Java Province, around 50.90\%, while the lowest population is in Gorontalo Province, around $1.65 \%$. According to the latest data (July 2012).

Limitations possessed by mentally retarded children are often used for things that are not good by the people who are around them, not only to be laughing material but also to become an inhuman lust for people. The level of threat of sexual violence against children with special needs in Indonesia is very often encountered. Even the threat of sexual violence in children with intellectual disabilities is higher when compared to normal children. The most common cases of sexual violence are girls with disabilities. The results of the study note that the threat of sexual violence in children with special needs is four times higher than normal children. So also preached by Tribunjogja.com about every month there are two cases of sexual violence that occurred in jogya, in 2015 there were 28 cases and 33 cases in 2016 and 2017 re-occurring increase of 35 cases of sexual violence against children disabled women. This can occur due to a lack of sexual education provided by parents and teachers at the school. because children are more at home or in their school environment. In harmony with that in Tribunjogja.comSentra Advocacy for Women with Disabilities and Children (SAPDA) record the occurrence of sexual violence that affects women with disabilities due to lack of information and education

Sexual education according to Ulwan Abdullah Nasih (2011: 15) is an effort to teach, raise awareness and illuminate problems related to sex, instincts and marriage. The results of observations and interviews of researchers at schools 
are extraordinary PERWARI Padang, has become a common view for teachers and surrounding people if there are children with special needs who hug, hold, even kissing in the toilet. This happened due to a lack of information or sex learning for children with special needs at the School extraordinary Perwari Padang especially for mentally retarded children. Their mentally retarded children will immediately practice what they see without judging from the bad and good side. However, it will be more controlled when there are people who teach them about the benefits and disadvantages of what they do. Because they will follow what is said or directed by the teacher or adult around them. One of the causes of their sexual behavior is sidelining, in addition to learning media innovation factors that are less than teachers, the role of parents is also highly expected to provide sex learning to children.

Sexual education does not teach how to have sex but the provision of overall reproductive health material (Santiana Nur Jannah, 2016). In addition to mentally retarded children who are quickly bored and tired in the learning process, the way they learn with normal children is very different. Their mentally retarded children learn by seeing directly and giving direct information on how to get along with women, because they are weak in their thinking power. But this kind of thing is often considered trivial by some teachers and parents, so that children will do things according to what they see in the field not what they feel like normal children.

Sexual development of children with special needs is not much different from other normal children, the sexual organ function of children with intellectual disabilities develops well and normally. Only his cognitive and motor development slower when compared to normal children. Based on the opinion of Keshav and Huberman (2006), Until now there are still many people who have wrong assumptions about the development of sexuality experienced by disabled youth or mental disabilities, namely those who have physical or mental disabilities do not have the desire or desire to have sex and people with mental and physical disabilities who have childish nature and depends on the people around him. But the reality is that in the field of disability teenagers feel the development of sexuality that goes like other normal children. Data obtained from observations at the extraordinary Padang Perwari school found several deviant sexual behaviors carried out by teenage young children like, children when learning in class often touches the genitals and then kisses their hands, children like to attach to the opposite sex, the child likes to hug the person around him, the child likes to point his hand to the genitals of the opposite sex, the child often holds the breast and the child likes to rub the genitals on the floor.

Innovation in the media of sexual learning for children in school must be done by every educator in giving understanding of sex to children. Because learning media that is not attractive will make children quickly bored and lazy to accept the lessons we will give. When the child has entered the level of boredom which leads to laziness, the purpose of the message or information provided by the educator will be difficult to understand by the child. According Hamalik, Oemar (1990), the main function is to study media as a teaching aid that also affect motivation, conditions, and learning environment. The use of learning media in the teaching and learning process can generate new interests and desires, 
generate motivation and stimulation of learning activities, and even bring psychological influences on learners (Falahudin Iwan, 2014).

The learning media that will be implemented must certainly be in accordance with the conditions and needs in each teacher's teaching material in the school. Therefore, the researcher used "Modification of Snakes and Ladder Games as a Psychosection Learning Media for Retarded Children". Where the aim is to shape child sexual psychology in reducing deviant behavior and reduce the level of sexual violence against young children.

\section{RESEARCH METHODS}

The type of research used in this study is qualitative research, with data collection methods using interviews and focus group discussion (FGD). This research was conducted on August 2 to September 292018 at the Special School Perwari, Padang west sumatera. In addition, the interview and documentation process is also carried out when collecting data. The informant for this study was chosen for several reasons.In order to gather information that creates a greater understanding of how student experience having a sport psychology consultant, data was collected from individuals who directly experienced the phenomena of interest (Patton, 2002). These Game Rules include:

1. In one field the stairs can only be played by 4 children at maximum, so the game can run effectively.

2. Children sit around the game field and include teachers or mentors in the game.

3. The game rules are almost the same as snake and ladders games usually, when the child draws numbers on the dice, the child must walk according to the number of dice obtained.

4. In some boxes there will be pictures that contain elements of sex education, when the child gets a pictorial box, the pembingbing or teacher must explain what examples are meant in the picture.

5. If the child has played the game for a number of times then the teacher / mentor can ask the child the purpose of the picture again.

6. after the teacher explains that the game can be resumed.

7. When the child stops at the box that has a picture of the ladder, the child must climb up to the box referred to by the ladder in the game.

8. If you get a down arrow that is almost like a snake, then the child must come down to the arrow in question.

9. each child can win the game if the child reaches the top in the 25th box.

10. The teacher or counselor can apply reward and punishment for children so that children are more eager to play. 
The purpose of this game is made include:

1. so that children can understand how to get along with the opposite sex.

2. so that children know what parts may be held by others except mothers (for women) or fathers (for men).

3 . in some game boxes there will be a picture that shows strangers and children running, meaning that when a foreigner wants to hold or hug them, they must run and ask for help from those around them.

4. so that the child does not fall into promiscuity or dating that can lead to sexual relations of the opposite sex.

5. In addition to the main objectives above, the goal is for children to be closer to their teachers and peers.

6. makes it easy for teachers to create creative learning media innovations because the materials used are easily available and affordable and some of the material is made of used materials.

The informants used were taken by necessity, consisting of 5 informants who were teachers who taught at the Special School Perwari, Padang. Subjects in this study amounted to 18 students who are children with special needs that existat the Special School Perwari, Padang. Of the 18 students there were 10 female students and 8 male students. The data collection techniques and tools use observation, interview and documentation methods. The data analysis technique in this research is more of a description of the results of observation, interviews and documentation. The data that has been obtained will be analyzed qualitatively and described in descriptive form (Patton, 2001: 103). Data analysis is "the process of arranging data sequences, organizing them into a pattern, category and basic description". The data analysis technique used in this study is to use steps as stated by BurhanBungin (2003: 70), namely as follows:

1. Data collection (data collection)

2. Data reduction (data reduction)

3. Display data

4. Verification and conclusions (conclution drawing and verification)

\section{RESULTS AND DISCUSSION}

Psychosexuals in the KBBI (large Indonesian dictionary) are all that are related to sex symptoms that arise because of psychological factors. One example of sexual symptoms is the release of clear fluid from the genitals. Sex symptoms can occur by several factors, because of the influence of stimuli from outside or within. One example of external factors is parenting or how they learn at school. According to Farisa Tiara Devi, et al (2013) the factors that influence sexual behavior are factors of increased libido, parenting, disability, parenting, and peer closeness. The results of observations in the field of the Retarded children's with 
their low cognitive abilities and lack of thinking power, they shamelessly masturbate in front of the teacher, friends and where they want to do it. In contrast to normal children who have a sense of shame if doing masturbation in public.

The lack of parental attention in sexual development of mentally retarded children influences the deviations of sexual behavior by children and is also a factor in the increase in sexual violence experienced by mentally retarded children in Indonesia. The definition of sex in the Indonesian dictionary is gender. In the Oxford Dictionary, sex is a statement about men or women and sex is things that relate to parts or organs of the body in men or women or differences and characteristics of men and women. Sexual learning must have been given since early childhood. Sexual learning is not only about the differences between men and women. Sexual problems in problems related to various sexual elements such as understanding of the genitals (reproductive organs) biologically and physiologically, hormonal functions, understanding gender and sexuality, understanding sexual desire, understanding sources of sexuality stimulation, understanding sexuality in children, adolescents, and age further, understanding the sex industry, understanding sexual deviations, understanding genetic elements, and so on.

Often the parents feel uncomfortable and embarrassed when discussing about sex organs and things that smell sex to children. In fact, without realizing it, with the development of technology that is progressing nowadays children can see through television, cellphones and pictures which they then practice with their peers. In fact, without realizing it, with the development of technology that is progressing nowadays children can see through television, cellphones and pictures which they then practice with their peers. Likewise, teachers who teach in special needs schools PERWARI, they mostly do not pay attention to all children, because there are so many children they will pay attention to while the number of teachers is less than the number of students. But as an educator the teacher should be more creative and more concerned about the development of child sex.

In order to reduce the level of sexual violence against children with special needs, especially children with mentally retarded. Of course the teacher's learning method using learning media that can attract the attention of mentally retarded children. Because mentally disabled children will get bored quickly and will be lazy if the method or media provided does not interest them. The use of colorful tools and in the form of educational games is very suitable to foster children's interest in learning. Because when the mentally retarded child feels happy with the media that we apply then the message or information we want to convey can be captured properly by the child. So that the learning objectives for children can be accomplished. A learning is said to be in accordance with the objectives to be achieved if the learning process in the classroom is adjusted to the characteristics of students, classroom settings and material delivery techniques (Sari Alfizah Ayu Indria, 2016).

Based on the observations of researchers at the extraordinary school Perwari Padang and through interviews with their teachers, sex learning for young children is only given directly orally to children. The direct aim is that there is no 
special material or clock for learning sex for children. The results of the interview with Buk Dewi, one of the mentally retarded children about sexual education applied at the extraordinary school PERWARI Padang on Thursday, November 132018 is when children engage in sexual activities with friends such as hugging, kissing and the like, the teacher just bans with words and convey that what they do is not allowed and in terms of religion we will sin. Whereas the purpose of sex learning to children at an early age is to be able to prevent the occurrence of deviant things to mentally retarded children. Rather than after all that happened, just told the child that what they were doing was wrong and incorrect. because there is a saying that prevention is better than cure.

From here the researcher modified the snake ladder game as a sex education media for mentally retarded children in the extraordinary school PERWARI Padang. The difference between snake and ladder games when compared to snake and ladder games which usually is located in the provision of educational pictures that explain how to relate to the opposite sex, whoever can hold us, what parts of the body can be seen and held and how take care of yourself if there are strangers who want to hold it. Sex education learning material in this game is more specifically designed so that children have information and knowledge on how to maintain and protect themselves when there are no parents and friends they know nearby.

When this snake ladder game media is applied to mentally retarded children in their extraordinary school, Perwari Padang shows high enthusiasm for the pictures in several game boxes. Because this game is indeed designed with colors that are liked by children. The rules of the game are not much different from snakes and ladders usually but in this game it must be accompanied by a teacher or someone who understands the meaning of the pictures in the game boxes. Because when children ask what the picture they mean, we must be able to explain it to the child. At the moment that's the explanation of learning sex education to children can be conveyed. Because when children ask, it shows they want to know about an information they see. When curiosity exists, memory in the brain tries to record whatever information is captured. Therefore, this game is highly recommended to apply at ice breaking or child break hours at the extraordinary school in Padang Perwari.

\section{CONCLUSIONS AND RECOMMENDATIONS}

Sexual violence against young children in Indonesia is included in the most cases. Then it is the responsibility for parents, teachers and the community around them to provide sex learning to children. The role of the teacher becomes the most important part after parents. The snake ladder game modification is one example of an interesting sex learning media for mentally retarded children in Officers 'Special Schools which can be applied by teachers at the Padang Officers' Special School. This snake ladder game modification is highly recommended to be one game that can be applied to ice breaking the learning process of mentally retarded children. In addition to helping children not to get bored in the learning process, sex education in schools is extraordinary. Officers become the most important part to mentally retarded children in the Padang School Special School. 
With trained mental sex psychology in children, deviant behavior and sexual violence of mentally retarded children can be minimized.

\section{REFERENCES:}

Abdullah Nandiyah. 2013. Mengenal Anak Berkebutuhan Khusus. Fakultas Psikologi UNWIDHA Klaten. Magistra No. 86 Th. XXV.

Blackhurst, A.E \& Berdine, HW (1981), An Intruduction to Special Education, Boston.

Efendi,M., 2006, Pengantar Psikopedagogik Anak Berkelainan.Jakarta,.Bumi Aksara.

Falahudin Iwan. 2014. Pemanfaatan Media dalam Pembelajaran.Jakarta Timur.Jurnal Lingkaran Widyaiswara, Edisi 1. No.4. diakses pada tanggal 25 september 2018.

Farisa Tiara Devi, dkk.2013.Faktor-Faktor Penyebab Perilaku Seksual Menyimpang Pada Remaja Tuna Grahita SLB N Semarang. Universitas Negeri Semarang. Developmental and Clinical Psychology 2 (1) (2013).

Halim Riski.9 desember 2017. setiap Bulannya Ada 2 Kasus Kekerasan Seksual Yang Terjadi Di Jogya.http://jogja.tribunnews.com/2017/12/09/setiap-bulannyaterjadi-2-kasus-kekerasan-seksual-terhadap-perempuan-disabilitas-di-yogya.

Terakhhir diakses 9 oktober 2018.

https://www.viva.co.id/berita/nasional/403525-guru-pencabul-5-siswi-tunagrahita ditangkap. terakhir diakses 6 oktober 2018.

Hamalik, Oemar. 1990. Metode Belajar dan Kesulitan-Kesulitan Belajar. Bandung: Tarsito

Jumadil Awwal.2017.Berdasarkan Data Dari Badan Pusat Statistik (BPS),jumlah anak berkebutuhan khusus(ABK) di Indonesia, Jakarta : MINA.

Patton,M. Q. (2002).QualitativeResearchand Evaluation Methods (3rded.). Thousand Oaks,CA:Sage Publications,Inc.

Santiana Nur Jannah.2016.Persepsi Guru Tentang Perkembangan Dan Pendidikan Seksual Anak Autistik Usia Remaja Di Slb Autis Citra Mulia Mandiri Yogyakarta. Jurnal Widia Ortodidaktika, Vol 5 No 8.

Sari Alfizah Ayu Indria.2016. Mengembangkan Rasa Ingin Tahu Dalam Pembelajaran Matematika Melalui Penemuan Terbimbing Setting Tps.Universitas Negeri Yogyakarta. Prosiding Seminar Matematika dan Pendidikan Matematika ISBN: 978-602-6122-20-9.

Ulwan, Abdullah Nasih 2011. Ada Apa dengan Seks?: Cara Mudah dan Benar Mengenal Seks, Alih Bahasa Imam Ghazali Masykur. Jakarta:Gema Insani Press.

Wahyu,Y.30/6/2016.Defenisi Anak Tuna Grahita. Info (K-MOE). https://www.infokmoe.id/2011/05/tunagrahita. terakhir diakses 9 oktober 2018.

Yosiani Novita.2014. Relasi Karakteristik Anak Tunagrahita Dengan Pola Tata Ruang Belajar Di Sekolah Luar Biasa. Universitas Katolik Parahyangan. EJournal Graduate Unpar,Vol. 1, No. 2. 